\title{
Degradation kinetics and in vitro digestive stability of selected bioactive compounds from a beverage formulated with butterfly pea flowers
}

\author{
Renata Oliveira Santos ${ }^{1^{*}}$ (Daura Monteiro Keller $^{2}$ Vanessa Sales de Oliveira ${ }^{1}$ (D) \\ Carlos Alberto Bucher ${ }^{3}(-)$ José Lucena Barbosa Junior ${ }^{1,2}$ (i) \\ Juarez Vicente ${ }^{1,2}$ Maria Ivone Martins Jacintho Barbosa ${ }^{1,2}(\mathbb{D})$
}

1Programa de Pós-graduação em Ciência e Tecnologia de Alimentos, Universidade Federal Rural de Rio de Janeiro (UFRRJ), 23897-000,
Seropédica, RJ, Brasil. E-mail: re.oliveira.ufrrj@gmail.com.br. "Corresponding author.
2Departamento de Tecnologia de Alimentos, Instituto de Tecnologia, Universidade Federal Rural de Rio de Janeiro (UFRRJ), Seropédica, RJ, Brasil.
${ }^{3}$ Departamento de Fitotecnia, Instituto de Agronomia, Universidade Federal Rural do Rio de Janeiro (UFRRJ), Seropédica, RJ, Brasil.

ABSTRACT: This study evaluated the effects of temperature on the pH of extracts of ascorbic acid and anthocyanins from petals of butterfly pea, as well as their in vitro digestive stability in model systems at 60,70 , and $80^{\circ} \mathrm{C}$. The pH values significantly decreased with an increase in the temperature $(P<0.05)$. The findings were similar for the degradation of anthocyanins and ascorbic acid, which followed first-order kinetics in all the systems. The samples heated at $80{ }^{\circ} \mathrm{C}$ presented the highest degradation rate ( $\left.k_{\text {obs }}\right)$, as well as higher percentages of degradation at the end of digestive stability in vitro.

Key words: thermal stability, anthocyanin, ascorbic acid, Clitoria ternatea L., digestive stability.

Cinética de degradação e estabilidade digestiva in vitro de compostos bioativos selecionados de uma bebida formulada com flores de feijão borborleta

RESUMO: Este estudo avaliou os efeitos da temperatura na estabilidade do ácido ascórbico, pH e antocianinas de pétalas de feijão borboleta, bem como a estabilidade digestiva in vitro do ácido ascórbico e antocianinas em sistemas modelo submetidos a 60,70 e $80{ }^{\circ} \mathrm{C}$. Os valores de pH diminuiram significativamente com o aumento da temperatura $(P<0.05)$. O mesmo foi observado para a degradação de antocianinas e ácido ascórbico, que seguiram cinética de primeira ordem em todos os sistemas. As amostras aquecidas a $80{ }^{\circ} \mathrm{C}$ apresentaram as maiores taxas de degradação $\left(k_{\text {obs }}\right)$, assim como maiores percentuais de degradação ao final da estabilidade digestiva in vitro.

Palavras-chave: estabilidade térmica, antocianina, ácido ascórbico, Clitoria Ternatea L., estabilidade digestiva.

\section{INTRODUCTION}

Anthocyanins are secondary metabolites that are widely distributed in nature; they are the most studied natural pigments. The interest in anthocyanins has increased significantly owing to their attractive color and water solubility, which highlight their important technological properties and beneficial health effects (PATRAS et al., 2010). Studies have linked the use of high temperatures to a reduction in anthocyanin content and the degradation of ascorbic acid (AA), indicating the importance of studying the stability of these two compounds, especially for industries where thermal processes and $\mathrm{pH}$ adjustments are commonly applied during production, which has an influence on the stability of anthocyanins and AA.

The butterfly pea flower (Clitoria ternatea L.), which belongs to the Fabaceae family, is native to tropical Asia. Its petals have blue to purple and white tones owing to the presence of anthocyanidins such as ternatin, preternatin, delfinidine, cyanidin, and malvidin (KUMAR et al., 2008). This variety of anthocyanins exhibits a protective effect against oxidative processes that naturally occur in living organisms; studies have also shown the beneficial effects of butterfly pea flower extracts, namely, their antihypertensive and anti-inflammatory properties, and the ability to reduce human LDL cholesterol levels (KUMAR et al., 2008).

Currently, a greater understanding regarding the mechanism of digestion of bioactive compounds found in food is required; this may contribute to and enhance the knowledge on the effects of these constituents on the human body. Digestive stability encompasses the nutrients that are not affected by the digestive process and can be properly 
observed in in vitro digestion of food systems. Although, a wide range of anthocyanins originating from different sources has been extensively studied (PÉREZ-VICENTE et al., 2002; LEE et al., 2005; CHEN et al., 2020), information concerning the digestive and thermal stability of anthocyanins from butterfly pea is scarce; this is also the case for their applicability in isotonics, which represents a potential area of research.

Traditionally, isotonic beverages are prepared using artificial colors; however, the substitution of synthetic dyes with natural ones has gained relevance owing to the growth in consumer demand for healthier products with low contents of synthetic substances. The main disadvantage of anthocyanins, compared with synthetic dyes, is their susceptibility to thermal degradation and $\mathrm{pH}$ modifications, which cause changes in the color and bioactivity of these natural substances. The use of high temperatures is associated with a reduction in the content of anthocyanins, owing to their degradation upon heating; which consequently, reduces pigment levels. $\mathrm{pH}$ changes are one of the main limiting aspects, since anthocyanins have chromophoric groups that are quite sensitive to $\mathrm{pH}$ alterations (JIANG et al., 2019). Hence, it is important to study the stability of anthocyanins, especially for industries where thermal processes and $\mathrm{pH}$ adjustments are commonly applied during production.

In this context, this study evaluated the thermal stability of AA and anthocyanins present in an isotonic beverage and some buffer solutions formulated with extracts of butterfly pea flower. Moreover, the in vitro digestive stability of both compounds in an isotonic model system formulated with extracts of butterfly pea flower was investigated.

\section{MATERIALS AND METHODS}

\section{Preparation of extracts}

Samples of butterfly pea flowers ( $C$. ternatea L.) were obtained from the Integrated Agroecological Production System (SIPA) located in Seropédica, Rio de Janeiro, Brazil. They were dried in an air circulation oven at $45^{\circ} \mathrm{C}$ for $5 \mathrm{~h}$ (KUMAR et al., 2008). Extract of butterfly pea flowers was prepared by mixing $2 \mathrm{~g}$ dried petals with $1 \mathrm{~L}$ distilled water, and the extract was used to formulate three model systems: (1) extract of butterfly pea flowers and phosphate/citrate buffer (Buffer), (2) extract of butterfly pea flowers and phosphate/citrate buffer containing AA (AA+Buffer), and (3) extract of butterfly pea flowers in an isotonic model (Isotonic).
The buffer solution was used to minimize changes due to different treatment conditions. The composition $(\% / \mathrm{L})$ of the isotonic model was $0.2 \%$ extract of butterfly pea flowers, $0.09 \%$ sodium chloride, $0.07 \%$ potassium chloride, $4 \%$ sucrose, $0.028 \%$ citric acid, and $0.028 \%$ AA. The $\mathrm{pH}$ of the model systems was adjusted to 2.5 .

\section{Thermal stability and degradation kinetics}

The thermal stability, degradation kinetics, and content of total monomeric anthocyanins (MA) and AA were evaluated using a scanning spectrophotometer (WUV-M51, WebLaborSP, Brazil). The samples were incubated, in a thermostated bath, at three different temperatures $(60$, 70 , and $80^{\circ} \mathrm{C}$ ) for $180 \mathrm{~min}$.

The degradation rate constant $(k)$ was determined using first order model (Equation 1) after linear regression analysis, which was used to determine the adequacy of the kinetic model.

$C(m g .1000 g-1)_{t}=C 0 \times \exp ^{(-k \times t)}$

where $\mathrm{C}_{0}$ is the initial anthocyanin content, $\mathrm{C}_{\mathrm{t}}$ is the anthocyanin content after a period of heating at a given temperature, and $k$ is the first-order rate constant. Half-life time $\left(\mathrm{t}_{1 / 2}\right)$ was calculated using equation 2 (DE ROSSO \& MERCADANTE, 2007).

$t_{\left(\frac{1}{2}\right)}(\min )=\frac{-\ln (0.5)}{k}$

To determine the effects of the temperature on the degradation kinetics of AA and MA, the constants obtained were adjusted using the Arrhenius equations (Equation 3) (HSU et al., 2012).

$$
k=k_{0} \times e \frac{-A e}{R T}
$$

where $A_{e}$ is the activation energy $(\mathrm{kJ} / \mathrm{mol}), \mathrm{R}$ is the universal gas constant $(8.314 \mathrm{~J} / \mathrm{mol} \mathrm{K}), \mathrm{T}$ is the absolute temperature $(\mathrm{K})$, and $\mathrm{k}_{0}$ is the frequency factor $\left(\mathrm{min}^{-1}\right)$. The $\mathrm{pH}$ values and $\mathrm{MA}$ and $\mathrm{AA}$ contents were monitored at each temperature $(60,70$, and $80{ }^{\circ} \mathrm{C}$ ); an aliquot of each sample was collected every $15 \mathrm{~min}$ up to $180 \mathrm{~min}$.

\section{Monomeric anthocyanin content, ascorbic acid content, and $\mathrm{pH}$ values}

The MA content was quantified using the differential $\mathrm{pH}$ method described by LEE et al. (2005), with cyanidin 3-glucoside as reference, and the absorbance was measured at 520 and 700 $\mathrm{nm}$. The AA content was measured at $265 \mathrm{~nm}$, the wavelength at which AA exhibits maximum absorbance, using a scanning spectrophotometer 
(WUV-M51, WebLaborSP) (RUIZ et al., 2016). pH readings were performed using a digital $\mathrm{pH}$ meter (PHS-3E, Even, Brazil) by inserting the electrode directly into the samples.

In vitro digestive stability of anthocyanins and ascorbic acid in isotonic model system

In vitro digestive stability was simulated in three stages: oral, gastric, and intestinal (MINEKUS et al., 2014). The isotonic model system was mixed with a simulated salivary fluid and the mixture was adjusted to $\mathrm{pH}$ 7.0. Then, the mixture was stirred at $95 \mathrm{rpm}$ (Novatecnica, Chilled, Brazil) for $2 \mathrm{~min}$ at $37^{\circ} \mathrm{C}$. After the oral phase, the solution was mixed with 50 $\mathrm{mL}$ of simulated gastric fluid and the mixture was adjusted to $\mathrm{pH}$ 2.0. Then, the mixture was stirred at $95 \mathrm{rpm}$ (Novatecnica, Chilled, Brazil) for $2 \mathrm{~h}$ at $37^{\circ} \mathrm{C}$. After complete gastric digestion, $50 \mathrm{~mL}$ of simulated intestinal fluid was added to the mixture, which was adjusted to $\mathrm{pH}$ 7.0. Then, the mixture was stirred at $95 \mathrm{rpm}$ (Novatecnica, Chilled, Brazil) for $2 \mathrm{~h}$ at $37^{\circ} \mathrm{C}$. Aliquots of gastric and intestinal digestion fluids were taken every $15 \mathrm{~min}$. The results were expressed as percentages of digestive stability, which refers to the percentage maintained after each step of in vitro digestion.

\section{Statistical analysis}

Statistical analysis was performed using Statistic (Statsoft version 7.0) and XLSTAT 2016 software. All the analyses were carried out in triplicate, and the results were expressed as averages followed by standard deviations. The differences between groups were evaluated using variance analysis and the Tukey test. A 5\% significance level was considered $(\mathrm{P}<0.05)$, and the average relative error $(\mathrm{E})$ was used to evaluate the fitting model, calculated using Equation 4 (BARBOSA JÚNIOR et al., 2013).

$$
E=\frac{1}{(N-1)} \sum_{i=1}^{N}\left|\frac{Y-\bar{y}}{Y}\right|
$$

where $\mathrm{E}$ is the average relative error, $\mathrm{N}$ is the number of experimental points, $\mathrm{Y}$ is the experimental value, and $\overline{\mathrm{Y}}$ is the predicted value.

\section{RESULTS AND DISCUSSION}

Heating affected the $\mathrm{pH}$ values of samples prepared with extract of butterfly pea flowers in an isotonic model (Isotonic), phosphate/citrate buffer (Buffer), and phosphate/citrate buffer containing AA (AA+Buffer) $(\mathrm{P}<0.05)$; the $\mathrm{pH}$ decreased with an increase in the temperature.
Similar findings were reported by GIRONÉS-VILAPLANA et al. (2016) for an isotonic drink made of lemon juice (Citrus limon (L.) Burm. f.) and maqui berry (Aristotelia chilensis). This trend can be due to the strong influence of $\mathrm{pH}$ on chemical structures and reactions, which can accelerate or attenuate molecular interactions. Heating can result in higher degrees of water dissociation in products containing water as the main constituent, such as isotonic beverages. Therefore, it can affect the $\mathrm{pH}$ value as it changes the hydrogen and hydroxyl ion concentrations (JIANG et al., 2019).

The degradation of MA (Figure 1A) and AA (Figure 1B) followed first-order kinetics at all the evaluated temperatures, in agreement with the results of previous studies carried out with model systems containing extracts of acai and acerola in isotonic drinks (DE ROSSO \& MERCADANTE, 2007) and juice of Urmu mulberry (Morus nigra L.) (KARA \& ERÇELEBI, 2013). These authors claim that the stability of anthocyanins depends on the temperature and $\mathrm{pH}$ associated with the chemical structure and co-pigmentation. Intermolecular copigmentation between anthocyanins, together with other compounds, produces an increase in color intensity and a shift in the maximum absorption length; the anthocyanins present in flower petals are accompanied by colorless flavones, which are co-pigments, and essential for color expression and anthocyanin stability (PATRAS et al., 2010). As expected, the highest degradation of MA occurred in the treatment at $80^{\circ} \mathrm{C}$ for all the three model systems (Figure 1A); the AA+Buffer system showed the highest rate of degradation at the end of $180 \mathrm{~min}$ at the three temperatures.

Kinetic models of AA have been described for alcoholic beverages (HSU et al., 2012) and tomato juice (ORDÓÑEZ-SANTOS \& MARTÍNEZGIRÓN, 2020). In the present study, the thermal degradation of AA was more pronounced during the first $15 \mathrm{~min}$ at all temperatures; the formulation subjected to $80{ }^{\circ} \mathrm{C}$ showed the highest percentage of degradation of AA. After $15 \mathrm{~min}$, the rate of AA degradation gradually decreased (Figure 1B). This may have been associated with the level of dissolved oxygen - which accelerates the degradation of AA — present at the beginning of the thermal process (QIU et al., 2018). The food matrix in which AA is inserted also has an influence on its stability; the molecular mobility of oxygen increases with a decrease in the viscosity of the product, as in the 


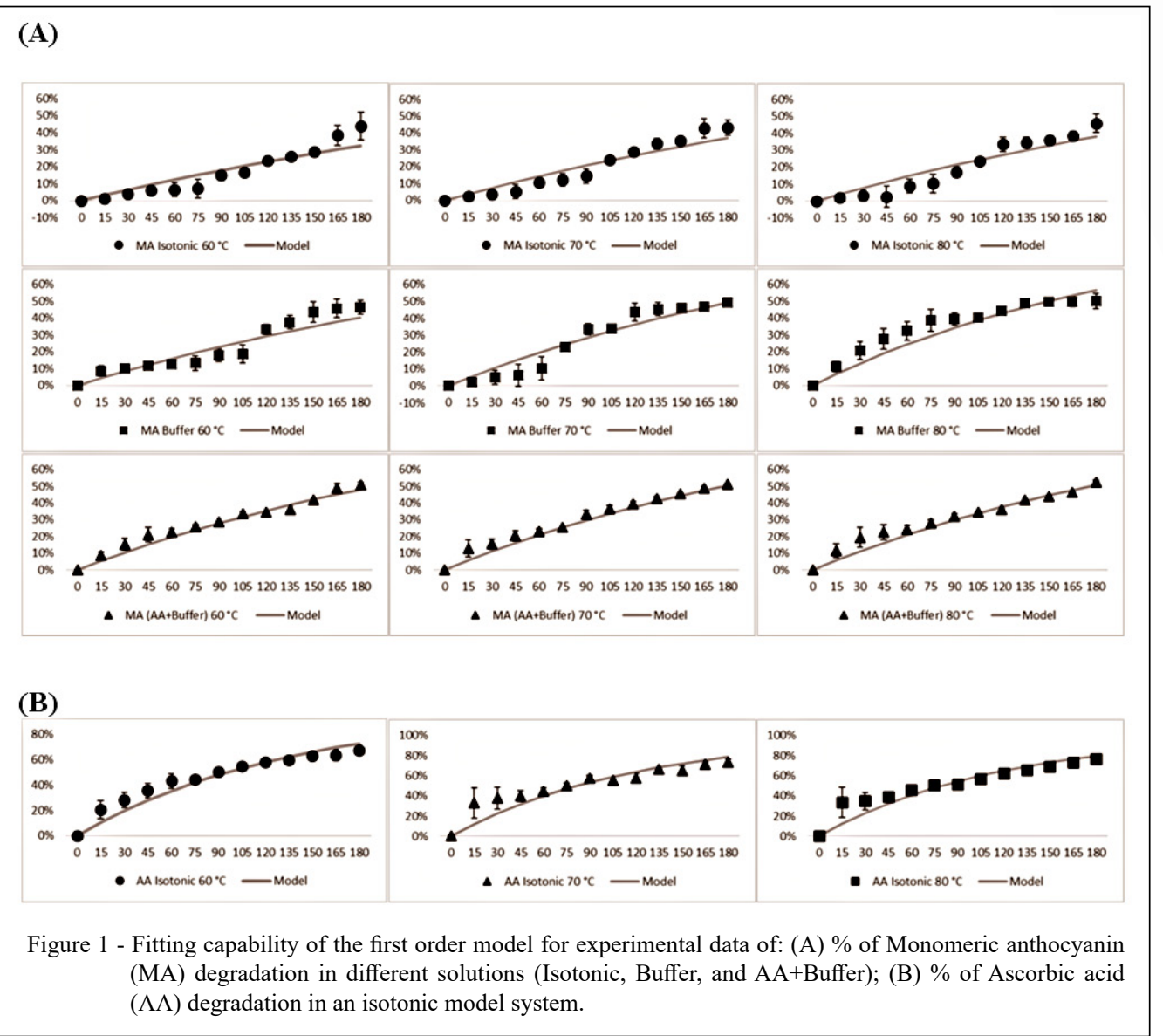

case of the model systems of the present study, thus increasing the degradation rates. Table 1 presents the parameters obtained from experimental data linear regression of thesystem degradation kinetics, the values of the determination coefficients, and the relative mean deviations for MA and AA. All samples presented determination coefficient close to 1.0, showing that the predicted models values for MA and AA presented a good correlation with the experimental data.

As indicated in table 1 , the degradation constant $\left(k_{\mathrm{obs}}\right)$ and the half-life time $\left(\mathrm{t}_{1 / 2}\right)$ of MA and AA were affected by heating in all the model systems. An increase in the temperature increased the values of the degradation constants and decreased the half-life time (Table 1), highlighting the effects of heating on the stability of the bioactive compounds. The degradation constant determined at $80{ }^{\circ} \mathrm{C}$ for MA was approximately 1.2 and 1.6 times higher than those at $60{ }^{\circ} \mathrm{C}$ for the isotonic model system and the buffer, respectively (Table 1).
An increase in the values of $k_{\text {obs }}$ was also reported by KARA \& ERÇELEBI (2013) for anthocyanins from Urmu mulberry juice ( $M$. nigra L.), in addition to a reduction in the values of the half-life. MARTYNENKO \& CHEN (2016) investigated the thermal degradation of anthocyanins from blueberry upon hydrothermodynamic (HTD) processing at 70, $80,87.5,95$, and $105^{\circ} \mathrm{C}$ for 0 and $400 \mathrm{~min}$. The values of $k$ increased with the temperature $(0.002$ $\min ^{-1}$ at $70{ }^{\circ} \mathrm{C}$ and $0.0179 \mathrm{~min}^{-1}$ at $105^{\circ} \mathrm{C}$ ), whereas the half-life time decreased $\left(346.6 \mathrm{~min}\right.$ at $70^{\circ} \mathrm{C}$ and 38.7 min at $105^{\circ} \mathrm{C}$ ); the results of the present study followed a similar trend.

The degradation constant determined at $80{ }^{\circ} \mathrm{C}$ for AA was approximately 1.2 and 1.1 times higher than $60{ }^{\circ} \mathrm{C}$ for the isotonic model system and the buffer, respectively (Table 1). The influence of the temperature on the stability of AA has been described by ORDÓÑEZ-SANTOS \& MARTÍNEZ-GIRÓN (2020) with regard to tomato juice (Solanum betaceum Cav.); they also reported 
Table 1 - Degradation constants $\left(\mathrm{k}_{\text {obs }}\right)$, half-life times $\left(\mathrm{t}_{1 / 2}\right)$, activation energies $\left(\mathrm{A}_{\mathrm{e}}\right)$, determination coefficients $\left(\mathrm{r}^{2}\right)$, $\mathrm{P}$ value $(\mathrm{P})$, and average relative errors $(\mathrm{E})$ for thermal degradation of monomeric anthocyanins and ascorbic acid.

\begin{tabular}{|c|c|c|c|c|c|c|c|c|}
\hline $\begin{array}{l}\text { Model } \\
\text { system }\end{array}$ & Component & Temperature $\left({ }^{\circ} \mathrm{C}\right)$ & $\begin{array}{c}k_{o b s} \times 10^{-4} \\
\left(\min ^{-1}\right)\end{array}$ & $\mathrm{t}_{1 / 2}(\min )$ & $r^{2}$ & $\mathrm{p} \times 10^{-10}$ & $\begin{array}{c}\mathrm{A}_{\mathrm{e}} \\
(\mathrm{kJ} / \mathrm{mol})\end{array}$ & $\mathrm{E}(\%)$ \\
\hline \multirow{3}{*}{ Isotonic } & \multirow{3}{*}{$\mathrm{AA}$} & 60 & 72.30 & 95.87 & 0.955 & 0.61 & \multirow{3}{*}{9.22} & 1.05 \\
\hline & & 70 & 85.00 & 81.55 & 0.905 & 59.60 & & 1.23 \\
\hline & & 80 & 87.20 & 79.49 & 0.934 & 13.76 & & 1.05 \\
\hline \multirow{3}{*}{ Isotonic } & \multirow{3}{*}{ MA } & 60 & 21.70 & 319.4 & 0.946 & 15.01 & \multirow{3}{*}{9.69} & 3.82 \\
\hline & & 70 & 25.70 & 269.7 & 0.970 & 0.34 & & 3.02 \\
\hline & & 80 & 26.50 & 261.6 & 0.955 & 5.36 & & 5.58 \\
\hline \multirow{3}{*}{ Buffer } & \multirow{3}{*}{ MA } & 60 & 28.80 & 240.7 & 0.955 & 1.70 & \multirow{3}{*}{23.33} & 1.88 \\
\hline & & 70 & 37.60 & 184.3 & 0.963 & 1.41 & & 3.58 \\
\hline & & 80 & 46.40 & 149.4 & 0.918 & 3.89 & & 1.31 \\
\hline \multirow{3}{*}{ AA + Buffer } & \multirow{3}{*}{ MA } & 60 & 36.40 & 190.4 & 0.980 & 0.00 & \multirow{3}{*}{4.00} & 0.97 \\
\hline & & 70 & 38.90 & 178.2 & 0.978 & 0.00 & & 0.98 \\
\hline & & 80 & 39.30 & 176.4 & 0.961 & 0.05 & & 1.07 \\
\hline
\end{tabular}

$\mathrm{MA}=$ monomeric anthocyanins; $\mathrm{AA}=$ ascorbic acid; $k_{\text {obs }}=$ degradation constant; $\mathrm{t}_{1 / 2}=$ half-life time; $\mathrm{A}_{\mathrm{e}}=$ activation energy; $\mathrm{r}^{2}=$ determination coefficient; $\mathrm{P}=\mathrm{P}$ value; $\mathrm{E}=$ average relative error.

that the values of $k$ increased upon heating, whereas the half-life time decreased.

The degradation of MA was more pronounced in samples containing the buffer solution than in the isotonic model system during all heating treatments (Table 1), suggesting that the presence of sugars and salts may favor pigment stability (DE ROSSO \& MERCADANTE, 2007). The highest degradation was observed when the buffer solution was heated at $80^{\circ} \mathrm{C}$, for which the degradation constant $\left(k_{\mathrm{obs}}\right)$ was 1.8 times higher than that determined for the isotonic model system $\left(80^{\circ} \mathrm{C}\right)$ (Table 1).

AA stability was also affected by the composition of the medium at all temperatures. The values obtained for the degradation constant $\left(k_{\mathrm{obs}}\right)$ were approximately 2 times higher than those of the samples containing the buffer solution (Table 1).

Higher values of activation energy $\left(\mathrm{A}_{\mathrm{e}}\right)$ are linked to a greater influence of the temperature on the degradation of the studied compound (KARA \& ERÇELEBI, 2013). Variation in the values of $A_{e}$ may be related to the different contents of soluble solids in the medium, and possible differences in composition between isotonic samples and those containing the buffer solution.
The digestive stability percentages of MA and $\mathrm{AA}$ in the isotonic samples formulated with the extract of butterfly pea flowers heated at 60,70 , and $80{ }^{\circ} \mathrm{C}$ are shown in figures 2 and 3, respectively. The temperature negatively influenced the digestive stability percentage of anthocyanins after in vitro digestion; this was mainly attributed to their thermal degradation. The control sample (not heated) and the sample incubated at $60{ }^{\circ} \mathrm{C}$ showed the highest digestive stability percentages of MA and $\mathrm{AA}$ at the end of in vitro digestion, whereas the isotonic sample incubated at $80{ }^{\circ} \mathrm{C}$ showed the lowest percentages.

At the end of intestinal digestion (240 min), the control sample presented a digestive stability percentage of MA of $62 \%$, whereas the isotonic system heated at $60{ }^{\circ} \mathrm{C}$ showed a stability percentage of $55 \%$. Lower percentages were determined for samples heated at $70(49 \%)$ and $80{ }^{\circ} \mathrm{C}(41 \%)$. Greater stability of anthocyanins was observed during the gastric phase, in which there were losses of $19.84 \%$ (control), $16.81 \%\left(60{ }^{\circ} \mathrm{C}\right)$, $16.76 \%\left(70{ }^{\circ} \mathrm{C}\right)$, and $18.58 \%\left(80{ }^{\circ} \mathrm{C}\right)$. The lower retention during the gastric phase in comparison with that during intestinal digestion indicates the higher stability of anthocyanins in acidic media, 


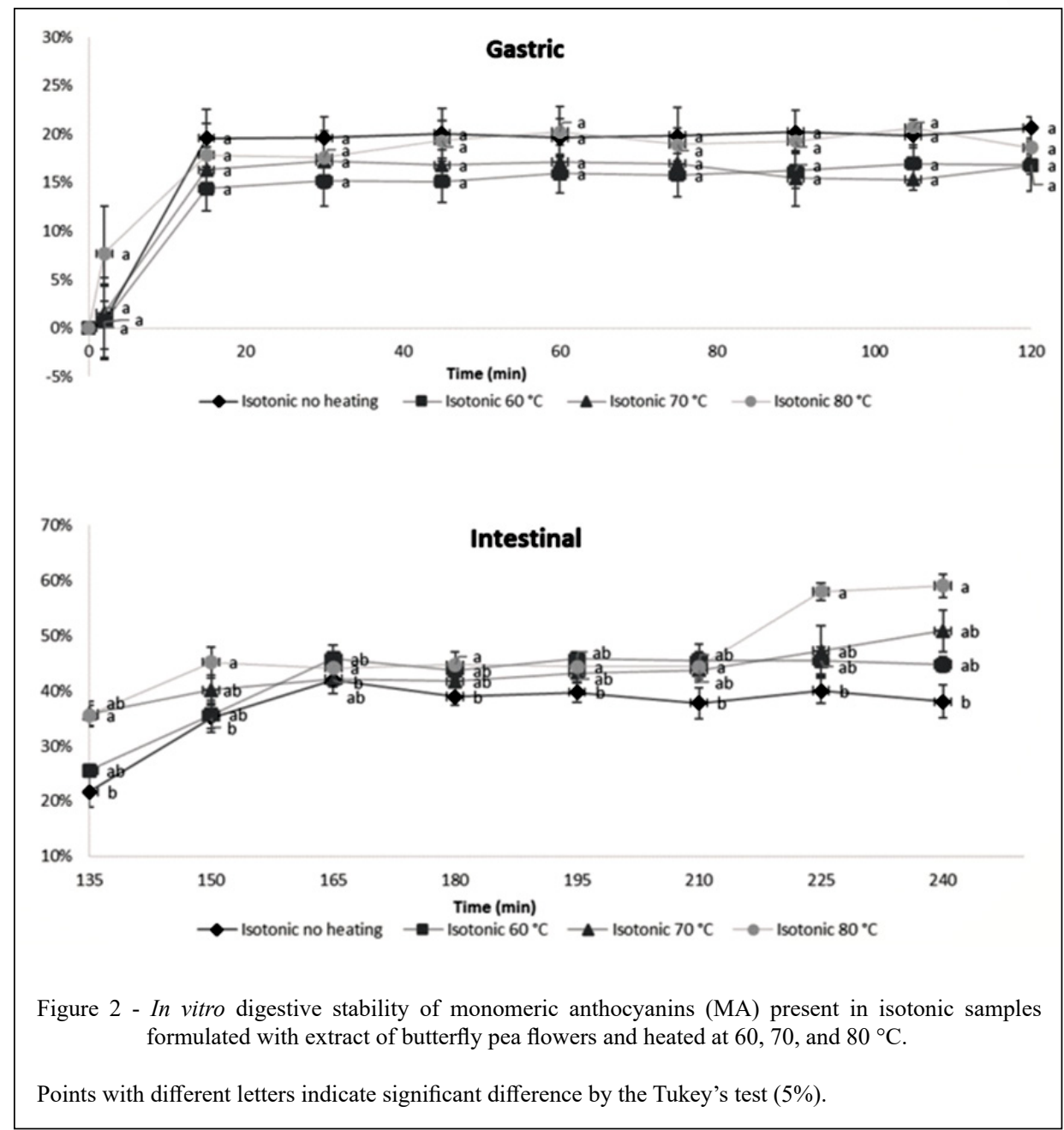

wherein the predominant species is the flavylium cation (CHEN et al., 2020). The digestive stability percentages determined at the end of in vitro digestion for AA reduced as follows: $60.98 \%\left(60^{\circ} \mathrm{C}\right)>57.70 \%$ (control) $>45.06 \%\left(70{ }^{\circ} \mathrm{C}\right)>31.63 \%\left(80^{\circ} \mathrm{C}\right)$, showing difference significant between the samples $(\mathrm{P}<0.05)$ (Figure 3). Additionally, a decrease in the loss of AA was also noticed at the end of gastric digestion (120 min), which is in agreement with the results of previous studies (PÉREZ-VICENTE et al., 2002).

PÉREZ-VICENTE et al. (2002) studied the in vitro digestive stability of $\mathrm{AA}$ in pomegranate juice and reported a loss of $29 \%$ after gastric digestion; such AA losses may be due to changes in the $\mathrm{pH}$ value and the presence of oxygen during gastrointestinal digestion.

\section{CONCLUSION}

The overall results of this study showed that the degradation of anthocyanins and ascorbic acid in samples containing extract of butterfly pea flowers followed a first-order kinetic reaction; these compounds presented the highest stability when the lowest temperature was applied during heating $\left(60^{\circ} \mathrm{C}\right)$. The $\mathrm{pH}$ value and stability of ascorbic acid in isotonic samples were affected by heating. Therefore, greater degradation was observed at higher temperatures. The isotonic sample heated at $80{ }^{\circ} \mathrm{C}$ showed the lowest percentage of digestive stability for anthocyanins and ascorbic acid after in vitro digestion, in agreement with the results of thermal stability analysis. However, further studies must be conducted to 


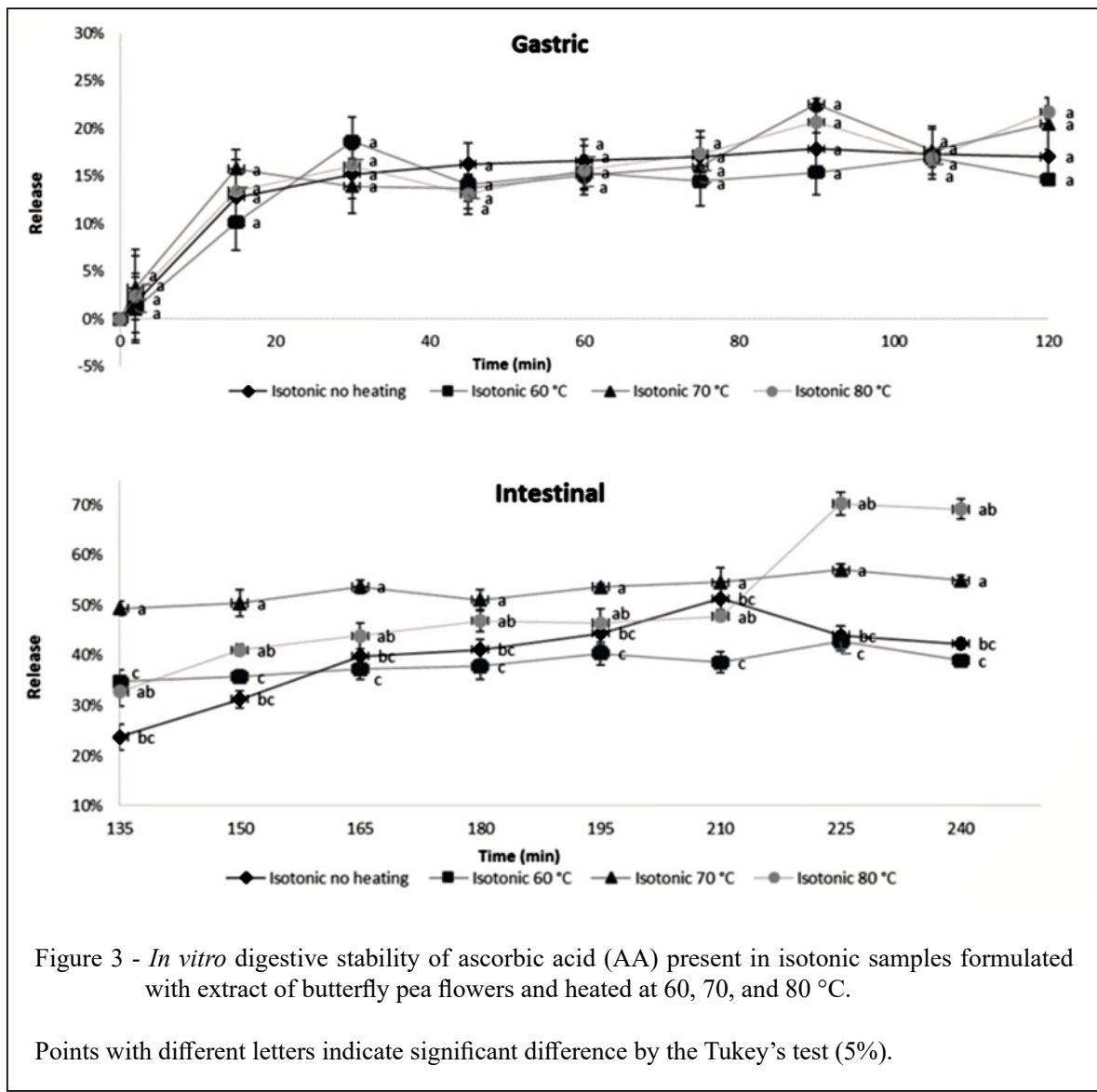

investigate the stability of anthocyanins from butterfly pea flowers in different food matrices in order to confirm their applicability as a natural dye in industries.

\section{ACKNOWLEDGEMENTS}

The authors are grateful for the financing of the project by the Brazilian Federal Agencies: "Coordenação de Aperfeiçoamento de Pessoal de Nível Superior" (CAPES) Financial Code 001, and "Conselho Nacional de Desenvolvimento Científico e Tecnológico" (CNPq).

\section{DECLARATION OF CONFLICT OF INTEREST}

The authors declare no conflict of interest.

\section{AUTHORS' CONTRIBUTIONS}

All authors contributed equally to the conception of the study and writing of the manuscript. All authors critically revised the manuscript and approved of the final version.

\section{REFERENCES}

BARBOSA JÚNIOR, J.L. et al. Mass transfer kinetics and mathematical modelling of the osmotic dehydration of orangefleshed honeydew melon in corn syrup and sucrose solutions. International journal of food science \& technology, v.48, n.12, p.2463-2473, 2013. Available from: <https://doi.org/10.1111/ ijfs.12237>. Accessed: Jun. 08, 2021. doi: 10.1111/ijfs. 12237.

CHEN, Y. et al. Bioaccessibility and biotransformation of anthocyanin monomers following in vitro simulated gastricintestinal digestion and in vivo metabolism in rats. Food $\&$ Function, v.11, p.6692-6692, 2020. Available from: <https:// doi.org/10.1039/D0FO90028A>. Accessed: Jul. 01, 2020. doi: 10.1039/D0FO90028A.

DE ROSSO, V. V.; MERCADANTE, A.Z. Identification and quantification of carotenoids, by HPLC-PDA-MS/MS, from Amazonian fruits. Journal of Food Chemistry, v.55, n.13, p.50625072, 2007. Available from: <https://doi.org/10.1021/jf0705421>. Accessed: Aug. 7, 2020. doi: 10.1021/jf0705421.

GIRONÉS-VILAPLANA, A. et al. Quality and microbial safety evaluation of new isotonic beverages upon thermal treatments. Food Chemistry, v.194, p.455-462, 2016. Available from:

Ciência Rural, v.52, n.5, 2022. 
$<$ https://doi.org/10.1016/j.foodchem.2015.08.011>. Accessed: Jul. 01, 2020. doi: 10.1016/j.foodchem.2015.08.011.

HSU, H.-Y. et al. Degradation of ascorbic acid in ethanolic solutions. Journal of Agricultural and Food Chemistry, v.60, p.10696-10701, 2012. Available from: <https://doi.org/10.1021/ jf3032342>. Accessed: Apr. 07, 2020. doi: 10.1021/jf3032342.

JIANG, T. et al. Degradation of anthocyanins and polymeric color formation during heat treatment of purple sweet potato extract at different pH. Food Chemistry, v.274, p.460-470, 2019. Available from: < https://doi.org/10.1016/j.foodchem.2018.07.141>. Accessed: Mar. 23, 2021. doi: 10.1016/j.foodchem.2018.07.141.

KARA, S. et al. Thermal degradation kinetics of anthocyanins and visual colour of Urmu mulberry (Morus nigra L.). Journal of Food Engineering, v.116, p.541-547, 2013. Available from: $<$ https://doi.org/10.1016/j.jfoodeng.2012.12.030>. Accessed: Apr. 07, 2020. doi: 10.1016/j.jfoodeng.2012.12.030.

KUMAR, V. et al. Validation of HPTLC method for the analysis of taraxerol in Clitoria ternatea. Phytochemical Analysis: An International Journal of Plant Chemical and Biochemical Techniques, v.19, p.244250, 2008. Available from: $<$ https://doi.org/10.1002/pca.1042 >. Accessed: Sept. 10, 2020. doi: 10.1002/pca.1042.

LEE, J. et al. Determination of total monomeric anthocyanin pigment content of fruit juices, beverages, natural colorants, and wines by the $\mathrm{pH}$ differential method: collaborative study. Journal of AOAC International, v.88, n.5, p.1269-1278, 2005. Available from: <https://doi.org/10.1093/jaoac/88.5.1269>. Accessed: Apr. 07, 2020. doi: 10.1093/jaoac/88.5.1269.

MARTYNENKO,A.;CHEN,Y.Degradationkineticsoftotalanthocyanins and formation of polymeric color in blueberry hydrothermodynamic (HTD) processing. Journal of Food Engineering, v.171, p.44-51, 2016. Available from: $<$ https://doi.org/10.1016/j.jfoodeng.2015.10.008>. Accessed: Apr. 01, 2021. doi: 10.1016/j.jfoodeng.2015.10.008.
MINEKUS, M. et al. A standardised static in vitro digestion method suitable for food-an international consensus. Food \& Function, v.5, n.6, p.1113-1124, 2014. Available from: <https://pubs.rsc.org/ en/content/articlepdf/2014/fo/c3fo60702j>. Accessed: Sept. 10, 2020. doi: 10.1039/C3FO60702J.

ORDÓÑEZ-SANTOS, L.E.; MARTÍNEZ-GIRÓN, J. Thermal degradation kinetics of carotenoids, vitamin $\mathrm{C}$ and provitamin $\mathrm{A}$ in tree tomato juice. International Journal of Food Science \& Technology, v.55, n.1, p.201-210, 2020. Available from: $<$ https:// doi.org/10.1111/ijfs.14263>. Accessed: May, 27, 2020. doi: $10.1111 /$ ijfs. 14263 .

PATRAS, A. et al. Effect of thermal processing on anthocyanin stability in foods; mechanisms and kinetics of degradation. Trends in Food Science \& Technology, v.21, n.1, p.3-11, 2010. Available from: < https://doi.org/10.1016/j.tifs.2009.07.004>. Accessed: Apr. 06, 2021. doi: 10.1016/j.tifs.2009.07.004.

PÉREZ-VICENTE, A. et al. In vitro gastrointestinal digestion study of pomegranate juice phenolic compounds, anthocyanins, and vitamin C. Journal of Agricultural and Food Chemistry, v.50, n.8, p.2308-2312, 2002. Available from: <https://doi. org/10.1021/jf0113833>. Accessed: Apr. 08, 2020. doi: 10.1021/ jf0113833.

QIU, J. et al. Formation and degradation kinetics of organic acids during heating and drying of concentrated tomato juice. LWT, v.87, p.112-121, 2018. Available from: <https://doi.org/10.1016/j. lwt.2017.08.081>. Accessed: Apr. 08, 2020. doi: 10.1016/j. lwt.2017.08.081.

RUIZ, B. G. et al. Spectrophotometric method for fast quantification of ascorbic acid and dehydroascorbic acid in simple matrix for kinetics measurements. Food Chemistry, v.211, p.583-589, 2016. Available from: <https://doi.org/10.1016/j. foodchem.2016.05.107>. Accessed: Apr. 02, 2020. doi: 10.1016/j. foodchem.2016.05.107. 